\title{
Fen Bilimleri Dersi ve Laboratuvar Uygulamalarına Yönelik Öğrenci ve Öğretmen Görüşleri: Bir Durum Çalışması
}

\section{Ramazan Soğukpınar ${ }^{1}$ \\ Prof. Dr. Kerim Gündoğdu ${ }^{2 *}$}

Gelis tarihi: 07.05.2020

Kabul tarihi: 11.06 .2020

\section{Atıf bilgisi:}

IBAD Sosyal Bilimler Dergisi

Sayı: 8 Sayfa: 275-294

Yll: 2020 Dönem: Güz

This article was checked by iThenticate. Similarity Index 08\%

Bu makalede araştırma ve yayın etiğine uyulmuştur.

\footnotetext{
1 Aydın Adnan Menderes Üniversitesi, Türkiye,

ramazansogukpinar68@gmail.com ORCID ID 0000000342528930

2 Aydın Adnan Menderes Üniversitesi, Türkiye, kerim.gundogdu@adu.edu.tr ORCID ID 0000-0003-4809-3405
}

\begin{abstract}
ÖZ
$\mathrm{Bu}$ araştırmanın amacı, ortaokul fen bilimleri dersi ve laboratuvar uygulamalarına yönelik öğrenci ve öğretmen görüşlerinin tespit edilmesidir. Çalışmada nitel araştırma yöntemlerinden durum çalışması deseni kullanılmıştır. Çalışmanın katılımcıları, 2019-2020 eğitim öğretim yılında, Türkiye'nin batı illerinden birinin merkez ilçesindeki bir devlet ortaokulunda görev yapmakta olan 6 (2 kadın, 4 erkek) fen bilimleri öğretmeni ve aynı ortaokulun tüm sınıflarında öğrenim gören 13 (5 kız, 8 erkek) öğrencidir. Veriler öğretmen ve öğrencilere yönelik hazırlanmış olan yarı yapılandırılmış görüşme formları ve yapılandırılmamış gözlem formu ile toplanmıştır. Toplanan veriler betimsel ve içerik analizi ile çözümlenmiştir. Araştırma sonucunda, öğretmenlerin laboratuvar uygulamalarında en çok karşılaştığı istenmeyen durumun deney malzemelerinin eksik olması, sınıfların kalabalık olması, laboratuvarda elektrik ve su tesisatının tam olmayışı olarak belirlenmiştir. Öte yandan öğretmenlerin çoğunluğu laboratuvar uygulamaları yapılırken öğrencileri gruplandırma, laboratuvarda güvenlik önlemlerinin alınmasını, öğrencilere rehberlik yapılması yeterli deney malzemelerinin temin edilmesi tavsiyesinde bulunmuştur. Yapılan gözlemler sonucunda da sınıfların kalabalık olduğu, sınıfların sınıf mevcuduna göre alan büyüklüklerinin yetersiz olduğu, sınıf yönetimini zorlaştıracak eylemler içerisinde olabildikleri gözlemlenmiştir.
\end{abstract}

Anahtar Kelimeler: bilimleri, laboratuvar uygulamaları, ortaokul öğrencileri, durum çalışması. 


\title{
Students' and Teachers' Views on Science Lesson and Laboratory Practices: A Case
} Study

\author{
Ramazan Soğukpınar ${ }^{1}$ \\ Prof. Dr. Kerim Gündoğdu ${ }^{2 *}$
}

First received: 07.05 .2020 Accepted: 11.06 .2020

\section{Citation:}

IBAD Journal of Social Sciences

Issue: 8

Pages: 275-294

Year: 2020

Session: Fall

This article was checked by iThenticate. Similarity Index 08\%

\footnotetext{
${ }_{1}^{1}$ Aydın Adnan Menderes University, Turkey,

ramazansogukpinar68@gmail.com ORCID ID 0000-0003-4252-8930

2 Aydın Adnan Menderes University, Turkey,

kerim.gundogdu@adu.edu.tr

ORCID ID 0000-0003-4809-3405
}

* Corresponding Author

\begin{abstract}
The aim of this study is to find out student and teachers perceptions related to elementary school science and laboratory practices. As one of the qualitative method, case study was used in the study. The participants were 6 ( 2 female and 4 male) science teachers and 13 ( 5 girls, 5 boys) students regsitered to middle school grades at a state elementary school in a central district of a province in the western Turkey, in the 2019-2020 academic year. Data were gathered from the participants through semi-structured interview form prepared as parallel format for both gorups and an unstructured observation form. Obtained data were analyzed through descriptive and content analysis techniques. As a result of the research, it was determined that the most undesirable situation encountered by teachers in laboratory implemantations was lack of experiment materials, crowded classes, and lack of electrical and water installations in the laboratory. On the other hand, the majority of teachers recommended grouping students while taking laboratory practices, taking security precautions in the laboratory, providing sufficient experimental materials to guide students. As a result of the observations made, it was determined that the classes were crowded, the size of the classes was insufficient according to the population. As a result of the observations made, it was observed that the classes were crowded, the size of the classes was insufficient according to the class size, and they could take actions that would make class management difficult.
\end{abstract}

Keywords: Science, laboratory implementations, middle school students, case study. 


\section{GÍRİS}

Günümüz dünyasında özünde bilişim ve iletişim teknolojilerinde olmak üzere çeşitli ilerlemelerin kaydedildiği tarihsel ve toplumsal değişimler gözlenmektedir ve bu değişimin yaşanmasındaki en önemli öğelerden biri de fen eğitimidir (Daşdemir ve Doymuş, 2012). Öğrenciler bilimin doğasını anlamlandırdıkları takdirde okullarda verilen fen eğitimiyle edindikleri bilgilerini günlük yaşamda uygulama firsatı bulabileceklerdir (Aydoğdu ve Yardımc1, 2013). Öğrencilerin okulda edindikleri bilgi ve becerileri günlük yaşamda kullanma becerilerini ölçmek amacıyla yapılan araştırmalardan birisi 'The Programme for International Student Assessment’ (PISA) uygulamasidır.

Türkiye'de eğitim kurumlarında her öğretim düzeyinde fizik, kimya ve biyoloji ile ilgili konuları içine alan fen bilimleri ağırlıklı olarak okutulmakta, ancak bu konuların öğrenilmesinde ve öğretilmesinde önemli sorunlarla karşılaşılmaktadır (Yıldız, Ilgaz ve Seferoğlu, 2010). OECD tarafindan 15 yaş grubundaki öğrencilerin belirli alanlarda kazandıkları bilgi ve becerileri değerlendiren ve üçer yıllık dönemler halinde yapılan ve uluslararası bir araştırma olan PISA 2015 uygulamasında Türkiye'ye ilişkin öğrenci performansları gerek ortalama puanlar ve gerekse yeterlik düzeyleri bazında değerlendirildiğinde fen okuryazarlığı alanında katılımcı tüm ülkelere ilişkin ortalama puanın 465 Türkiye'nin ise ortalamasının 425 olduğu görülmüştür (Taş, Arıcı, Özarkan ve Özgürlük, 2016). Öte yandan 2018'de yapılan PISA sonuçlarına göre Türkiye'nin fen okuryazarlı̆g alanındaki ortalama puanı 2015 yılına oranla 43 puanlık artış göstererek 468'e yükselmiştir. Dolayısıyla fen okuryazarlığı alanında büyük iyileşme görülmüştür (MEB, 2019). Bu noktadan hareketle, Türkiye'de fen eğitiminde daha başarılı olunması için Milli Eğitim Bakanlığı (MEB), fen bilgisi öğretim programlarında çeşitli güncellemeler yapmıştır (MEB, 2018). En son yapılan güncellemede, fen eğitiminin temel amacının, tüm bireylerin fen okuryazarı olarak yetiştirilmesi, diğer öğretim programlarında (MEB, 2005; 2013) belirtildiği üzere tekrar vurgulanmış ve öğretim programında alana özgü beceriler kısmında, laboratuvar uygulamalarının önemi bilimsel süreç becerilerinde ifade edilmiştir (MEB, 2018). Dolayısıyla bilgi çağı da denilen bu yüzyılda, eğitim sisteminin temel amacının öğrencilere bilgiyi hazır olarak vermekten çok, bilgiye nasıl ulaşabileceklerini göstermek ve zihinsel süreç becerilerini kazandırmak olduğu ifade edilmiştir (Doğru ve Aydoğdu, 2003).

$\mathrm{Bu}$ tür becerilerin kazandırılmasında önemli bir işlev üstlenen yapılandırmacı yaklaşımda, öğrenci merkezli bir anlayışla eğitim-öğretimin yapılması esastır. Öğrencilerin aktif olarak öğrenme ortamına katılması sağlanır ve bunun gerçekleşmesi için de uygun ortam hazırlanır (Bada, 2015). Diğer derslerde temele alındığı gibi, bu yaklaşımla fen eğitiminde öğrencilerin daha önceden edindikleri bilgileri, yeni bilgilerle sentezleyerek anlamlı ve kalıcı öğrenme sağlanması hedeflenmektedir (Balım, Kesercioğlu, Evrekli ve İnen, 2009). Öğrenciler gerçekten öğrendikleri fen ile ilgili bilgileri zihinlerinde yapılandırmış ise konu ile ilgili yorum yapabileceklerdir (Şaşan, 2002). Geleceğin fizikçisi, kimyası, biyoloğu ve mühendisi gibi bilim insanlarının yetişmesi, kendi yönlerini ve yeteneklerini keşfetmesi ilköğretim düzeyinde verilen fen eğitimi sayesinde gerçekleşmektedir (Arslan, 2000).

Yapılandırmacı yaklaşımın uygulamada görülmesini sağlayan öğrenme etkinliklerinden birisi de fen bilgisi laboratuvarlarında yapılan uygulamalardır (Ketpichainarong, Panijpan ve Ruenwongsa, 2010). Laboratuvarın fen eğitiminde etkin rol oynadığ 1 ve büyük öneme sahip olduğu bilinmektedir (Orbay, Özdoğan, Öner, Kara ve Gümüş, 2003). Laboratuvar, öğrencilerin öğretim ortamında birbirleriyle etkin olarak iletişim ve etkileşim halinde olmalarını sağlayan; edindikleri bilimsel bilgileri kavramalarına ve anlamlandırmalarına yardımcı olan ve 21. yüzyıl becerilerinden bilimsel düşünme becerilerini geliştirmelerine firsat veren aktif ögrenme ortamlarıdır (Hofstein ve Lunetta, 2003). Laboratuvarda yapılan etkinlikler, öğrencilerin bilimi daha iyi anlamlarına, fene ve bilimsel uygulamalara yönelik tutumlarında olumlu gelişmeler yaşanmasına (Uluçınar, Cansaran ve Karaca, 2004; Harman, 2011) yardım eder. Derste işlenen soyut fen konularını, yaparak yaşayarak öğrenme yoluyla daha somut hale getirerek, öğrenilenleri daha kalıcı hale getirmektedir (Harman, 2011).

Fen eğitiminde öğretmenlerin yeterliği (Ültay, Usta ve Ültay, 2020) kadar, fene yönelik inanç ve düşünceleri de öğretim ortamında yapılacak etkinliklere yönelik kararlarda etkili olmaktadır (Levitt, 2001). Hizmet öncesinden ve hizmet sırasında elde edilen tür yeterlikler etkili ve verimli bir öğrenme sağlanabilmesi bakımından önemlidir. Eğitim kurumlarında, eğitim ve öğretim etkinliklerini olumsuz 
yönde etkileyen her türlü davranış istenmeyen davranış olarak belirtilmektedir (Alkaş, 2010; Pala, 2005). Diğer bir deyişle olumsuz öğrenci davranışları, sınıfta ya da herhangi bir öğretim ortamında eğitim faaliyetlerini aksatan, bunun yanında sınıftaki diğer öğrencileri de olumsuz olarak etkileyen her türlü davranış olarak tanımlanmaktadır (Akçadağ, 2007). Öğrenme ortamı kimi zaman değişmektedir. Özellikle fen derslerinde dersin işlendiği ortamlardan birisi de laboratuvarlardır. Laboratuvarda ders işlenirken ya da uygulamalar yapılırken öğrencilerin öğrenmelerinde etkili olan bazı faktörler bulunmaktadır. Örneğin, sözlü, yazılı veya elektronik kılavuzlar, etkinlikler sırasında kullanılacak araçgereçler, öğrenci-öğretmen ve öğrenci-öğrenci arasındaki karşılıklı etkileşim, uygulama sonunda öğrencilerin, öğretmenlerinin kendilerini nasıl değerlendireceği algıs1, öğretmenlerin tutumu, hazırbulunuşluğu, alan bilgisi ve davranışları öğrencilerin öğrenmelerinde etkili görülmektedir (Hofstein ve Mamlok-Naamon, 2007). Bununla birlikte ilkokul ve ortaokul düzeyinde yapilacak deney ve etkinliklerin çoğunun laboratuvarda yapılması gerekirken, öğrencilerin laboratuvardaki araç-gereçleri tanımaması, bu araç gereçlerin kullanım amacını bilmemesi, öğretmenlerin ilgili etkinlik ve deney malzemelerini öğrencilerin kullanımına izin vermemesi gibi birçok farklı nedenlerle laboratuvarda yapılması gereken etkinlikler yapılmamaktadır (Başdaş, Kirişcioğlu ve Oluk, 2006).

Konu ile ilgili alanyazın incelendiğinde fen bilimleri dersinin öğretiminde veya laboratuvarda karşılaşılan zorlukların tespit edilmesine yönelik öğretmen görüşleri (Erdemir, 2007; Geçer ve Özel, 2012; Gökyer ve Doğan, 2016; Karaca, Uluçınar ve Cansaran, 2006; Tuncel ve Fidan, 2018; Türkoğlu ve Dağ, 2018; Üstün ve Demir, 2015) ile ilgili çalışmalar yapıldığı görülmektedir. Bu konuda öğrenci görüşleri ile ilgili olarak fen bilgisi öğretimine, öğrenme ortamına ya da bu ortamlarda karşılaşılan sorunlara yönelik (Doğru ve Aydoğdu, 2003; Kaplan, 2011) ve fen programındaki etkinliklerle ilgili (İdin ve Aydoğdu, 2016; Kurtuluş ve Çavdar, 2011) tespit çalışmaları yapıldığı görülmektedir. Bununla birlikte öğretmenlerle yapılan diğer çalışmalarda, öğretmenlerin laboratuvar kullanımına yönelik görüşlerinin (Güneş, Şeker, Germi ve Can, 2013; Kılıç ve Aydın, 2018; Uluçınar, Cansaran ve Karaca, 2004; Uluçınar, Doğan ve Kaya, 2008), öz yeterlilik inançlarının (Kılıç, Keleş ve Uzun, 2015) ve yeterliliklerinin (Böyük, Demir ve Erol, 2010; Geçer, 2018) incelendiği görülmektedir. Öğretmen adaylarının fen öğretimi laboratuvar uygulamaları dersine yönelik eğitim ihtiyaçlarının belirlendiği (Ceylan, Güzel Yüce ve Koç, 2019) ve fen bilgisi öğretmen adaylarının laboratuvar ortamında edindikleriyle bilişsel esneklikleri arasındaki ilişkinin (Parlaktaş, 2018) incelendiği çalışmalar da alanyazında yer almaktadır. Ayrıca konu ile ilgili alanyazında bu çalışmaların dışında, cinsiyetin (Baysal ve Mutlu, 2019) ve çağdaş yaklaşımlara dayalı laboratuvar uygulamalarının öğrencilerin fen laboratuvarına yönelik tutumlarına etkisinin (Baysal, Mutlu ve Kış, 2019); bir yöntem olarak laboratuvarın fen bilimleri dersinin niteliğine uygunluğunun (Kırpık ve Engin, 2009); laboratuvarda meydana gelen kazaların nedenlerinin (Aydoğdu ve Yardımc1, 2013) ve fen derslerinde kullanılan farklı deney tekniklerinin öğrencilerinin bilimsel süreç becerilerine etkilerinin araştırıldığı çalışmalar da vardır. Diğer taraftan biyoloji öğretmen adaylarının laboratuvara yönelik semantik farklılıklarının (Çınar ve Kurt, 2019); FeTeMM etkinlik merkezli laboratuvar dersinin sınıf öğretmenliği adaylarının fen öğretimine yönelik öz-yeterlik ve problem çözme becerileri üzerine etkilerinin (Durmuş, 2019); fen bilgisi öğretmenlerinin laboratuvar uygulamaları ile ilgili yeterlikleri, tutumları ve karşılaşılan problemlerin (Keskin Geçer, 2018) ve öğrencilerin fizik laboratuvarı malzemelerini tanıma düzeylerinin (Kızılcık, Çağan ve Yavaş, 2019) belirlendiği çalışmalara da alanyazında rastlamak mümkündür. Çalışmaların çoğunun nicel çalışmalar olduğu da ayrıca gözlenmektedir.

$\mathrm{Bu}$ araştırmanın amacı, ortaokul fen bilimleri dersi ve laboratuvar uygulamalarında karşılaşılan güçlüklerin belirlenmesi ve laboratuvar ortamında öğrenci davranışlarının nasıl şekillendiğinin detaylı olarak incelenmesidir. Bu amaç doğrultusunda aşağıdaki araştırma sorularına yanıt aranmıştır:

1-Ortaokul fen bilimleri dersi ve laboratuvar uygulamalarına yönelik öğrenci ve öğretmen görüşleri nelerdir?

2-Ortaokul fen bilimleri dersi ve laboratuvar uygulamalarına yönelik öğrenci davranışları nasıl şekillenmektedir? 


\section{YÖNTEM}

Çoklu veri toplama yoluyla derinlemesine bilgi edinmek ve kontrol edilemeyen bir olayı derinlemesine inceleme firsatı yaratan amacıyla yapılan bu nitel durum çalışması (Creswell, 2018; Yıldırım ve Şimşek, 2016), tekli iç içe geçmiş durum çalışmasıdır (Yin, 2014). İç içe geçmiş tek durum deseni, tek bir durum içerisinde iki veya daha fazla alt tabaka ya da birimin olduğu yani birden fazla analiz durumunun olduğu araştırma desenidir. Yapılan çalışmada araştırmacının deneyimleri sonucunda belirlenen laboratuvar ve fen bilimleri dersinde karşılaşılan zorlukların ve bu derse ait öğrenci davranışlarını belirleyen tek bir durum olduğu görüşüyle hareket edilmiştir. Analiz birimi bir ortaokuldur ve okul 5, 6, 7 ve 8 sinıflar olmak üzere alt tabakalara ayrılmıştır.

\section{Çalışma Bağlamı}

Çalışmanın yürütüldüğü devlet okulunda yaklaşık 1200 öğrenci bulunmakta olup ihtiyacı karşılamak amacıyla 16 derslikli dört katlı yeni bina yapılmıştır. Yeni binanın alt katı ana sınıfı ve diğer sınıflar için ayrılmıştır. Üst katlarında ise müdür odası, müdür yardımcısı odası, rehberlik odası, fen teknoloji laboratuvarı, öğretmenler odası, memur odası, hizmetli odası, öğretmen ve öğrenci tuvaletleri bulunmaktadır. Okul bahçesine 2008 yılında ilçe belediyesi ve okulun kendi imkânlarıyla öğretmen ve öğrencilerin kullanımı için mini halı saha yaptırılmıştır. Ayrıca okul A, B ve C blok olmak üzere 3 bloktan oluşmaktadır. A blokta 9 adet derslik, Bilişim Teknolojileri sınıfı, öğretmenler odası ve arşiv bulunmaktadır. B blokta 10 adet derslik, 2 özel eğitim sınıfı, öğretmenler odası bulunmaktadır. C blokta 15 adet derslik, 1 adet anasınıfı ve lavaboları, müdür odası, müdür yardımcısı odaları, öğretmenler odası, memur odası, 1 fen ve teknoloji laboratuvarı, rehberlik servisi, hizmetli odası, kalorifer dairesi bulunmaktadır. Bunların yanında okulda teknoloji ve tasarım sınıfı da bulunmaktadır. Öte yandan okulun faaliyet alanlarına ilişkin hizmetler, kurumdaki tüm çalışanlar tarafından işbirliği ve uyum içerisinde yürütülmektedir. Yöneticiler, eğitim faaliyetleri ile ilgili herhangi bir sorun yaşandığında veya bir problemin çözülmesi gerektiğinde, sürecin her aşamasında öğretmenlerin ve personelin görüş ve önerilerine başvurmaktadır. İletişimler çoğunlukla yüz yüze toplantı ve bireysel görüşmeler şeklinde olmakla birlikte, resmi yazışma sistemi de etkin kullanılmaktadır. Okulun resmi internet sitesi ve kurumsal elektronik posta adresi de aktif olarak kullanılmaktadır. Yöneticiler tarafından, öğretmenlere eğitim faaliyetlerinde yeteri kadar serbestlik alanı bırakılmaktadır. Dolayısıyla bu durumda ögretmenlerin daha verimli olması ve kendilerini güvende hissetmeleri sağlamaktadır. Yapılan hizmetler, tüm paydaşların kolayca ulaşabileceği şeffaf bir şekilde sunulmaktadır. Öğrenci velilerinin eğitim faaliyetlerine mümkün olduğu kadar aktif katılımları sağlanmaktadır. Ancak genelde orta düzeyde meslek gruplarında hizmet veren veliler çoğunluktadır. Kadın velilerin etkinliklere katılımı daha fazladır.

\section{Katılımcılar}

2019 yılı güz döneminde gerçekleştirilen araştırmanın katılımcıları Aydın ili Nazilli ilçesindeki bir devlet ortaokulunda görev yapmakta olan 7 fen bilimleri öğretmeninin tamamı ve her sınıf $(5,6,7$ ve 8) seviyesinden seçilen üçer olmak üzere, toplamda 12 öğrenci olarak belirlenmiştir. Ancak belirlenen bir öğretmen araştırmaya katılmak istemediğinden ve çalışmada etik olarak gönüllülük esas olduğundan, bu öğretmen çalışma grubuna dahil edilmemiştir. Bu nedenle amaçlı (ölçüt) örnekleme yöntemi ile 6 fen bilimleri öğretmeni çalışmaya katılmıştır. Amaçlı örnekleme, zengin bilgiye sahip olduğu düşüncesi ile hareket edilen durumlarda derinlemesine çalışılmasına imkan veren örnekleme yöntemidir (Patton, 1987). Diğer bir ifadeyle ölçüt örnekleme, araştırma öncesinde belirlenen bir dizi ölçütü kapsayan durumlarda kullanılmaktadır. Bu araştırmada belirlenen ölçüt ise, seçilen okulun ilçenin merkezi konumunda olması, öğrenciler açısından sosyoekonomik düzeyinin orta-iyi seviyede olması ve genel akademik başarının düşük olmamasıdır. Tüm bu nedenlerde dolayı, çalışılan ortaokulun belirlenmesi ölçüt (amaçl1) örneklemeye uygundur.

Seçilen sınıflar ve öğrenciler ise amaçlı örnekleme yöntemlerinden maksimum çeşitlilik örneklemesi ile tespit edilmiştir. Maksimum çeşitleme, göreceli olarak küçük bir örneklem oluşturma amaciyla yapılan ve araştırılan duruma ilişkin belirlenecek bireylerde çeşitliliği maksimum düzeyde yansıtmaktır (Yıldırım ve Şimşek, 2016). Bu çalışmada öğrencilerin seçimi yapılırken okul yönetiminden öğretmenlerin bir önceki yılın fen bilimleri dersi not çizelgesi temin edilmiştir. Not 
çizelgelerine bakılarak öğrencilerin fen bilimleri dersi başarı puanları değerlendirilmiş; aynı zamanda fen bilimleri dersine giren öğretmenlerin görüşlerine başvurulmuştur. Sonuçta, tüm siniflardan birer olmak üzere toplamda 4 sınıf belirlenmiştir. Bu sinıflarda öğrenim görmekte olan öğrencilerden, öğretmenler tarafından belirlenen akademik başarı ve davranış yönünden üst düzey, orta düzey ve alt düzey birer öğrenci olmak üzere toplamda 3 öğrenci seçilmiştir. Bu nedenlerden ötürü, araştırmanın çalışma grubunda toplamda 4 sınıftan 12 öğrenci ve 6 fen bilimleri öğretmeni yer almaktadır. Ancak 7. sınıflardan bir öğrenci daha görüşmelere dahil olduğundan sayı 13 'e çıkmıştır. Tüm öğrencilere araştırmaya katılımlarının gönüllülük esasına dayalı olduğu, araştırmanın herhangi bir safhasında çıkabilecekleri belirtilmiş ve her biri için gönüllü onam formları doldurulmuştur.

\section{Veri Toplama Araci}

$\mathrm{Bu}$ araştırmada veriler, nitel veri toplama tekniklerinden yarı yapılandırılmış görüşme formu ve yapılandırılmamış gözlem formu ile toplanmıştır. Görüşmeye başlamadan önce katılımcılara izin verdikleri takdirde görüşmelerin ses kayıt cihazıyla kaydedileceği ve araştırmanın gizliliğiyle ilgili etik unsurlar yeniden hatırlatılmıştır. Kaydedilen görüşmeler, görüşme bitiminde katılımcılara isterlerse dinletilebileceği, gerekirse istemedikleri kısımların kayıttan silinebileceği söylenmiştir. Araştırmacı tarafından geliştirilen yarı yapılandırılmış öğrenci ve öğretmen görüşme formu, katılımcıların kişisel bilgileriyle ilgili sorular ve fen bilimleri dersi ve laboratuvar uygulamalarında gerçekleşen istenmeyen durum ve öğrenci davranışlarını belirlemek amacıyla hazırlanan 6 sorudan oluşmuştur. Sorular hazırlanırken yanıtı 'evet' veya 'hayır' olarak belirlenen kapalı uçlu sorulardan kaçınılmış, gerekli durumlarda ise sondalar aracılığıyla derinlemesine bilgi elde edilmeye çalışılmıştır. Form hazırlandıktan sonra fen bilgisi eğitimi doktora programında nitel araştırmalar dersi veren bir akademisyenin uzman görüşüne ve dil açısından anlaşılırlık için bir Türkçe öğretmenine başvurulmuştur. Sonrasında hazırlanan görüşme formu birer öğretmen ve öğrenciyle ses kayıt cihazı kullanılarak pilot görüşmeler yapılmıştır. Pilot görüşme sonucunda, formun uygunluğu test edilerek değiştirilmeden asıl görüşmelerde kullanılmasına karar verilmiştir. Görüşmelerde öğrencilere ve öğretmenlere sorulan soruların büyük oranda paralel olmasına özen gösterilmiştir. Örneğin 'Fen bilimleri dersinde yapacağınız laboratuvar etkinliklerini nerede yapıyorsunuz?' veya 'iyi bir laboratuvar uygulamasının yapıldığı ortamı tanımlar mısınız?' vb. sorular her iki katılımcı grup tarafından cevaplanarak cevaplarda kontrol mekanizması sağlanmıştır.

Çalışmada ayrıca gözlem yapılmıştır. İki öğretmenin dersinde gözlem yapılmasına izin vermemesinden dolayı, görüş̧e yapılan öğrencilerin dersine giren dört farklı fen bilimleri öğretmenin fen bilimleri derslerinde birer ders saati süresince yapılmıştır. Her sınıf düzeyinden bir öğretmen ders ortamında gözlemlenmiştir. Öğretmenlerin video kaydı gerçekleştirilmesini istememeleri üzerine kayıt yapılmamıştır. Gözlemler yapılırken araştırmacı tarafından notlar tutulmuştur.

\section{Araştırmacının Rolü}

Çalışmada araştırmacı, konu ile ilgili derinlemesine bilgi toplamak için öğretmenlerle doğrudan yarı yapılandırılmış görüşmeler yapmıştır. Bunun için öncelikle görev yaptığı okuldaki fen bilimleri ögretmenlerine daha öncesinde fen bilimleri dersi ve laboratuvar uygulamaları hakkında kendileriyle görüşme yapmak istediği belirtilmiştir. Görüşme isteğini kabul eden öğretmenlerden uygun oldukları gün ve saati belirlemeleri istenmiş ve belirlenen gün ve saat için randevu alınmıştır. Belirlenen randevu günlerinde sessiz bir ortam olması bakımından görüşmeler fen bilgisi laboratuvarında gerçekleştirmiştir. Bunun yanında, öğrencilerin laboratuvar ortamındaki davranışlarının nasıl şekillendiğini belirlemek amacıyla yapılan gözlemler yapılandırılmamış laboratuvar çalışması olarak katılımcı olmayan gözlemci rolünde gerçekleştirilmiştir. Grup tarafindan araştırmacının gözlem yaptığı bilinmekte; ancak araştırmacı grup etkinliklerine katılmamaktadır.

\section{Verilerin Analizi}

Kişisel bilgiler ile ilgili veriler betimsel olarak, görüşme ve gözlemlerden elde edilen veriler ise içerik analizi ile çözümlenmiştir. İçerik analizi yapılırken yüksek lisans ve doktora eğitimi sürecinde nitel araştırmalar dersini almış ve başarıyla tamamlamış, biri araştırmacının kendisi diğeri matematik 
eğitimi programında doktora öğrencisi iki ayrı araştırmacı tarafından veriler kodlanmış ve ikinci yazar tarafından kontrolü sağlanmıştır. Daha sonra çalışmanın güvenirliği açısından Miles ve Huberman'ın (1994) önerdiği Güvenirlik=Görüş Birliği/(Görüş Birliği+Görüş Ayrıllğı) güvenirlik formülü kullanılarak kodlayıcılar arası görüş birliği 0.82 bulunmuştur. Çalışmada öğretmen ve öğrenci görüşlerinden alıntılar yapılırken öğretmenler için 'Ö1, Ö2' gibi, öğrenciler için 'Öğ.1, Öğg. 2' gibi kodlamalar yapılmış ve önemli görülen alıntılara tırnak (“...”) içerisinde yer verilmiştir.

\section{BULGULAR}

Kişisel bilgiler ile bulgular iliş̧in kişisel bilgiler Tablo 1'de gösterilmiştir. Araştırmaya katılan altı öğretmenden dördünün 8 . sınıflarda derse girdiği gözlenmektedir. Kıdem yılı açısından incelendiğinde, üç öğretmenin 16-20 yıl arasında deneyime sahip olduğu görülmektedir. Aldıkları eğitime bakıldığında ise dört öğretmenin lisans mezunu olduğu ve mezun olunan bölüm değişkenine göre dört öğretmenin fen bilgisi öğretmenliği mezunu olduğu görülmektedir.

Tablo 1. Öğretmenlerin Kişisel Bilgileri

\begin{tabular}{llll}
\hline Özellik & f & Özellik & f \\
\hline Sinıf düzeyi & & Ĕgitim durumu & 1 \\
5. sinıf & 2 & 3 Yıllık Eğitim Enstitüsü & 4 \\
6. sinıf & 2 & Lisans & 1 \\
7. sinıf & 3 & Yüksek Lisans & \\
8. sinıf & 4 & & 4 \\
\hline Kıdem yılı & & Mezun olunan Bölüm & 1 \\
$10-15$ yil & 1 & Fen Bilgisi Öğretmenliği & 1 \\
$16-20$ y1l & 3 & Fizik Öğretmenliği & \\
$21-30$ yil & 1 & Fizik Kimya Biyoloji (FKB) & \\
31 y1l ve üzeri & 1 & & \\
\hline
\end{tabular}

Öğretmenlerle fen bilimleri ve laboratuvar uygulamalarında karşılaşılan güçlükler konusunda yapılan görüşmeler sonucunda elde edilen temalar, kategoriler ve bu kategorilere ait kodlar Tablo 2'de verilmiştir.

Tablo 2. Fen Bilimleri Dersi ve Laboratuvar Uygulamalarına Ait Öğretmen Görüşleri

\begin{tabular}{|c|c|c|c|}
\hline Temalar & Kategoriler & Kodlar & $\mathbf{f}$ \\
\hline \multicolumn{4}{|l|}{ Tema 1: Mekan } \\
\hline \multirow{20}{*}{$\begin{array}{l}\text { Alt tema 1: } \\
\text { Laboratuvar }\end{array}$} & \multirow{8}{*}{ Alt kategori 1: Yetersizlik } & Deney malzemesi & 6 \\
\hline & & Elektrik tesisatı & 5 \\
\hline & & Alan büyüklüğü & 5 \\
\hline & & Su (lavabo, musluk vb.) & 4 \\
\hline & & Malzeme dolabı & 4 \\
\hline & & Öğrenci tabure ve masası & 3 \\
\hline & & Laboratuvar kullanım talimatnamesi & 2 \\
\hline & & Ayrı malzeme odası & 1 \\
\hline & \multirow{4}{*}{$\begin{array}{l}\text { Alt kategori 2: Laboratuvar } \\
\text { kullanım sıklığ1 }\end{array}$} & Ayda bir-iki kez & 2 \\
\hline & & Ara sira- bazen & 2 \\
\hline & & Her hafta & 1 \\
\hline & & Çok nadir & 1 \\
\hline & \multirow{5}{*}{$\begin{array}{l}\text { Alt kategori 3: (istenmeyen } \\
\text { durum) }\end{array}$} & Oturma düzeni & 6 \\
\hline & & Öğrenci sayısının fazlalığı & 5 \\
\hline & & Tehlikeli durum & 4 \\
\hline & & Gürültü & 3 \\
\hline & & Yönetici ilgisizliği & 1 \\
\hline & \multirow{3}{*}{$\begin{array}{l}\text { Alt kategori } 4 \text { :Öğrenci } \\
\text { davranışları }\end{array}$} & Kontrolün sağlanamaması & 2 \\
\hline & & Merak & 1 \\
\hline & & İzinsiz malzeme kullanımı & 1 \\
\hline \multicolumn{4}{|l|}{ Tablo 2 (Devamı) } \\
\hline \multirow[t]{2}{*}{ Alt tema 2: Sinıf } & Alt kategori 1: Yetersizlik & Fiziki ortam & 2 \\
\hline & Alt kategori 2: Güçlük & Öğrenci davranışları & 3 \\
\hline
\end{tabular}


Sinıfların kalabalık olması 2

Dersi somutlaştıramamak 1

Gereksiz konuşmalar 1

Öğrenme güçlükleri 1

Alt kategori 1: Yaparak yaşayarak

Kalıcılik 5

öğrenme Aktif öğrenme 4

Alt kategori 2: Duyuşsal

özellikler

Tema 2: Deney

ve Etkinlikler

\begin{tabular}{ll} 
Aktif öğrenme & 4 \\
\hline İlgi & 4 \\
Sorumluluk & 1 \\
Özgüven & 1 \\
\hline Laboratuvar sayısını artırma & 1 \\
Öğrencileri gruplandırma & 4 \\
Yeterli deney malzeme temini & 4 \\
Öğretmen rehberliği & 3 \\
Güvenlik önlemleri & 3 \\
Malzeme alanını artırma & 3 \\
Öğretmen eğitimi & 1 \\
Malzemelerin sınıflandırılması & 1 \\
Konuların sırlaması & 1 \\
\hline
\end{tabular}

Alt kategori 3: Tavsiyeler

12

Tablo 2 incelendiğinde fen bilimleri ve laboratuvar uygulamalarında karşılaşılan güçlükler konusunda yapılan görüşmeler sonucunda mekan ve deney ve etkinlikler şeklinde 2 tema, mekan teması altında laboratuvar ve sınıf ş̧eklinde iki alt temanın elde edildiği görülmektedir. Laboratuvar alt teması; yetersizlik, laboratuvar kullanım sıklığı, istenmeyen durum ve öğrenci davranışları şeklinde belirlenen 4 kategoriden oluşmuştur. Sınıf alt teması, yetersizlik ve istenmeyen durum kategorilerinden oluşmuştur. Deney ve etkinlikler teması ise yaparak ve yaşayarak öğrenme, duyuşsal özellikler ve tavsiyeler olarak 3 kategoriden oluşmuştur.

Laboratuvar alt temasındaki yetersizlik kategorisinden elde edilen kodlamalardan yola çıkarak; altı ögretmenin deney malzemesi, beș ögretmenin elektrik tesisatı ve alan büyüklüğ̈̈, dört öğretmenin malzeme dolabı ve su tesisatı (lavabo, musluk vb.), üç öğretmenin öğrenci tabure ve masası, iki öğretmenin laboratuvar kullanım talimatnamesi ve bir öğretmenin ayrı malzeme odasının laboratuvardaki eksiklikler olarak belirttikleri görülmektedir. Örneğin malzeme yetersizliği ile ilgili olarak bir öğretmen (Ö2) şunları dile getirmektedir:

"Bir deney yapacağımm, sadece bir kiş̧inin ya da bir grubun yapabileceği yeterli sayıda malzeme var. İşte 35, 36 kişilik sinıflar var. Dörder kişilik gruplar oluştursam 9 grup yapıyor. 9 grubun tamamına yetecek kadar sayıda malzeme yok. Bırakın 9 grubu 3 gruba yetecek malzeme yok (Ö2)”.

Diğer bir öğretmen (Ö5) ise "malzeme yetersizliğimiz var. Malzemeyi başka bir öğretmen götürmüş oluyor deney yapmak istesem de yapamıyorum elim boş gidiyorum. Istenmeyen böyle durumlar oluşabiliyor malzemenin yetersizliğinden (Ö5)" şeklinde görüş belirtmiştir. Laboratuvardaki alt yap1 ve alan yetersizlikleri ve ile ilgili olarak bir öğretmen (Ö2) "Sinıfların kalabalıklığından dolayı grupları oluşturabileceğim yeterli alan da yok. Yeterli tesisatı sağlayacak alt yapı da yok. Her gruba elektrik vermem gerecek öyle bir alt yapım yok", bir başka öğretmen (Ö6) "Şöyle söyleyim bi kere, bizim en başta yakındı̆̆ımız olay sınıflarımızın çok kalabalık olması. Keşke imkânımız olsa laboratuvarı büyültsek ve iki bölümden oluşsa, hani gruplara ayırsak bu kalabalıklığl biraz azaltabilsek...”.

Laboratuvar kullanım sıklı̆̆ kategorisine ait kodlardan yola çıkarak, iki öğretmenin ara-sıra (bazen) ve iki öğretmenin ayda bir-iki kez, bir öğretmenin her hafta ve bir öğretmeninde çok nadir olarak derslerde laboratuvarı kullandığ görülmektedir. Genel olarak öğretmenlerin ara sira laboratuvarda uygulama yaptıkları görülmektedir. Laboratuvar kullanım sıklığı ile ilgili olarak örneğin bir öğretmen (Ö4) "Çok sık değil işin doğrusu. Düzgün laboratuvar olmadı̆̆ından ara sıra.."; bir başka öğretmen (Ö5) ise "Bu sene daha girmedik laboratuvara. Geçen sene birkaç kez yaptık burada laboratuvarda ama..." şeklinde itirafta bulunmuştur. 
Fen bilimleri dersinin laboratuvarda işlenişine yönelik 'istenmeyen durumlar' kategorisindeki kodlamalardan yola çıkarak; öğretmenlerin tamamının oturma düzenine, beş öğretmenin öğrenci sayısının fazlalığına, dört öğretmenin tehlikeli durum oluşmasına, üç öğretmenin gürültü olmasına ve bir öğretmenin yönetici ilgisizliğine dikkat çektikleri görülmektedir. Örneğin bir öğretmen (Ö5) yöneticilerin laboratuvar uygulamaları hakkında ilgili olmalarını istediğini ifade etmiștir. Diğer bir öğretmen (Ö2) "Kesinlikle. Çocukları kontrol etmek problem oluyor. Sürekli bir şeyleri kurcalamaya çalışıyorlar. Bu çok büyük bir tehlike arz ediyor. Bunun dışında sınıfi kontrol etmek zorlaşlyor. Çünkü sınıflarımız çok kalabalık!” sözleriyle tehlikeye dikkati çekmektedir. Bu durumu örneklerle ifade eden bir başka öğretmenin (Ö5) sözleri manidardır:

"Burada mesela oturma düzeni daha tam ayarlanmadiğı için, herkes isteğine göre oturduğu için daha çok gürültü oluyor sinıftakinden. O yüzden de buraya getirmeye cesaret edemiyorum. Bunun haricinde istenmeyen durum, çocukların teneffüste dolapları karıştırması. Ya da herhangi bir malzeme kırıldı̆̆ında böyle bir durum olabilir (Ö5).”

Fen bilimleri dersinin işlenişine yönelik laboratuvardaki 'öğrenci davranışlardan kaynaklanan sorunlar' kategorisinden elde edilen kodlamalardan yola çıkarak iki öğretmen kontrolün sağlanamadığına, bir öğretmen öğrencilerin meraklı olduğuna ve bir öğretmen de izinsiz malzeme kullanımına dikkat çekmişlerdir. Örneğin bir öğretmen (Ö2) laboratuvarda öğrencileri kontrol etmenin zor olduğu ifade ederken diğer bir öğretmen (Ö4) "işte asitlerin olduğu dolaba gidiyor. Çocuklar kurutulmuş dondurulmuş hayvanlar varsa onları karıştırmayı merak ediyor. bu durumda kargaşa oluyor yani o çocuğa bakarken.”, bir başka öğretmen (Ö5) ise "bunun haricinde istenmeyen durum, çocukların teneffüste dolapları karıştırması." şeklinde görüş belirtmiştir.

Tablo 2 incelendiğinde, fen bilimleri dersinin işlenmesine yönelik 'yetersizlik' kategorisine yönelik kodlamalardan yola çıkıldığında iki öğretmenin fiziksel ortama ilişkin yetersizliğe dikkat çektiği görülmektedir. Bir öğretmen (Ö3) sınıfın, ders için küçük olduğunu belirtirken; bir diğer öğretmen (Ö1) ise "Mutlaka karşılaştı̆̆ımız anlar oluyor. Gerek sınıftaki fiziki ortamın yetersizliğinden, gerek sınıfta ögrenci davranışlarından kaynaklanan sorunlarla karşılaş̧ı̆̆ımız oluyor (Ö1)" şeklinde görüş bildirmektedir.

Sınıfta, fen bilimleri dersinin işlenmesine yönelik 'istenmeyen durumlar' kategorisine yönelik kodlamalardan yola çıkıldığında üçer öğretmenin öğrenci davranışlarına ve gürültüye; bir öğretmenin "Yani sınıflarımızın kalabalık olması dolayısıyla oluyor (Ö6)" ve diğer bir öğretmenin "ancak sinıf kalabalık olduğu için de laboratuvara getiremiyorum (Ö2)" şeklinde sınıfların kalabalık olduğuna ve başka bir öğretmenin (Ö2) "Dersi canlandıramadığım için tabii ki yaşıyorum. Çocuklar için anlamlı olmuyor ders" şeklinde dersi somutlaştıramadığına ilişkin istenmeyen duruma dikkati çektiği görülmektedir. Başka bir öğretmenin (Ö5) "yani çocukların birbirleriyle olan şeyleri var. o bana bulaşt,, birbirlerini şikayet olayları var ilkokul çocukları gibi. o, hocam ayağıma bastı gibi. Bu tür şeyler de etkiliyor sinıf ortamını (Ö5)"; bir başka öğretmenin (Ö1) "öncelikle sinıflardaki ögrenci davranışlarında istendik davranışların her zaman elde edilememesi sorunların başında geliyor (Ö1)" şeklinde öğrenci davranışlarından dolayı istenmeyen durumların oluştuğuna yönelik görüş bildirmektedir.

Tablo 2 incelendiğinde, fen bilimleri dersinin işlenmesine yönelik 'deney ve etkinlikler' temasındaki yaparak ve yaşayarak öğrenme alt kategorisine' yönelik kodlamalardan yola çıkıldı̆̆ında deney ve etkinlik yapıldığında, beş öğretmenin öğrenmede kalıcılık sağlandığını, dört öğretmenin ise öğrencilerin derse aktif olarak katıldıklarına ilişkin yaparak ve yaşayarak öğrenmenin etkililiğine dikkat çektiği görülmektedir. Bir öğretmen (Ö1) "mesela deney ve etkinlikleri belli bir aşamadan sonra onlara yaptırabiliriz. Onları burada ön plana çıkartıp kendimizi arka plana çekebiliriz. Çünkü hani yaparak yaşayarak öğrenme diye bir şey var (Ö1)“, bir başka öğretmen (Ö3) "isterdim ki hani oyun hamuru, kum, kinestetik kum gibi malzemeler olacak ki çocuklar hani sadece deney değil de gelecekler de bunun gibi şeylerle yapacaklar. Hem eğlenceli olurdu, hem de ögrenciler aktif olacaktı" şeklinde görüş bildirmektedir.

Fen bilimleri dersinin işlenmesi ile ilgili olarak, deney ve etkinlik temasındaki duyuşsal özellikler alt kategorisine yönelik kodlamalardan yola çıkıldığında dört öğretmenin öğrencilerin ilgilerini çektiğine, 
bir öğretmenin öğrencilerin sorumluk almalarını sağladığını ve bir başka öğretmenin ise öğrencilerin özgüveninin gelişeceğine dikkat çektiği görülmektedir. Bununla ilgili olarak örneğin bir öğretmen (Ö2) "çocuklar dokunabileceği şeylerle karşılaştıklarında ilgisini çekmek kolay oluyor" ve bir diğer ögretmen (Ö1) "öğrenci sorumluluk aldıkça özgüveni gelişecektir. bu da derse karşı olan ilgisini geliştirecektir (Ö1)” şeklinde görüş bildirmektedir.

Deney ve etkinliklerin yapılması ile ilgili tavsiyeler kategorisinden elde edilen kodlamalardan yola çıkarak dörder öğretmenin yeterli deney malzeme temini ve öğrencileri gruplandırma, 3'er öğretmenin ögrencilere rehberlik yapılması, güvenlik önlemleri alma ve malzeme alanını artırma tavsiyelerinde bulunduğu Tablo 2'de görülmektedir. Bu tavsiyelerle ilgili olarak örneğin, bir öğretmen (Ö6) "bir kere öncelikle malzeme anlamında hiçbir sıkıntı yaşamamamı gerekiyor", bir başka öğretmen (Ö1) "Her dersi önümüzdeki derste hangi konuyu işleyeceksek o konuyla ilgili bilgilendirme yapıp, gruplara ayırarak hazırlı gelmelerini ister, buna göre yapılması gereken bir deney veya etkinlik varsa planlamaları için yardımcı olur ama o etkinliği yapma işini onlara teslim ederdim”, diğer bir öğretmen ise (Ö3) " bir de kesinlikle laboratuvarların büyük olmasını isterdim" şeklinde görüş belirtmişlerdir. $\mathrm{Bu}$ tavsiyelerin dişında bir öğretmen (Ö4) "eğitim de almamız gerekiyor. yani laboratuvar nasıl kullanılır, nasıl girilir, nasıl çıkılır, neler yapılır, bunların çocuklara hem anlatılması hem kurs düzenlenmesi..." şeklinde görüş bildirerek laboratuvar kullanımı ile ilgili eğitim verilmesini belirtmiştir. Diğer yandan başka bir öğretmen (Ö1) "laboratuvar sayısını artırmak ilk yapacağım iş olurdu" şeklinde tavsiyelerde bulunmuşlardır.

Öğrencilerle fen bilimleri dersi ve laboratuvar uygulamalarında karşılaşılan zorluklar konusundaki görüş̧meler sonucunda elde edilen temalar, kategoriler, kodlar ve frekans değerleri Tablo 3 'te verilmiştir.

Tablo 3. Fen Bilimleri Dersi ve Laboratuvar Uygulamalarına Ait Öğrencilerin Görüşleri

\begin{tabular}{|c|c|c|c|}
\hline Temalar & Kategoriler & Kodlar & $\mathbf{f}$ \\
\hline \multicolumn{4}{|l|}{ Tema 1: Mekan } \\
\hline \multirow{19}{*}{$\begin{array}{l}\text { Alt Tema 1: } \\
\text { Laboratuvar }\end{array}$} & \multirow{11}{*}{ Kategori 1: Yetersizlik } & Deney malzemesi & 11 \\
\hline & & Öğrenci tabure ve masası & 4 \\
\hline & & Alan büyüklüğü & 3 \\
\hline & & Malzeme dolabı & 3 \\
\hline & & Su (lavabo, musluk vb.) & 2 \\
\hline & & Yeni teknolojik aletler & 2 \\
\hline & & Elektrik tesisatı & 1 \\
\hline & & Lab kullanım talimatnamesi & 1 \\
\hline & & Temizlik & 1 \\
\hline & & Ayrı malzeme odası & 1 \\
\hline & & Isinma & 1 \\
\hline & \multirow{4}{*}{ Kategori 2: Laboratuvar kullanım s1klığ1 } & Çok nadir & 6 \\
\hline & & Ara sira- bazen & 4 \\
\hline & & Ayda bir-iki kez & 2 \\
\hline & & Her hafta & 1 \\
\hline & \multirow{3}{*}{ Kategori 3: İstenmeyen durum } & Oturma düzeni & 4 \\
\hline & & Gürültü & 4 \\
\hline & & Öğrenci sayısının fazlalığı & 2 \\
\hline & Kategori 4 :Öğrenci davranışları & Aşırı isteklilik & 1 \\
\hline \multirow{5}{*}{$\begin{array}{l}\text { Alt tema 2: } \\
\text { Sinıf }\end{array}$} & \multirow[t]{5}{*}{ Kategori 1: Güçlük (istenmeyen durum) } & Arkadaşlar arası davranışları & 4 \\
\hline & & Gereksiz öğrenci konuşması & 3 \\
\hline & & Gürültü & 2 \\
\hline & & Konuları anlayamamak & 1 \\
\hline \multirow{2}{*}{\multicolumn{4}{|c|}{ Tablo 3 (Devamı) }} \\
\hline & & & \\
\hline \multirow[b]{4}{*}{$\begin{array}{l}\text { Tema 2: } \\
\text { Deney ve }\end{array}$} & \multirow{3}{*}{ Kategori 1: Yetersizlik } & Öğrenme amac1 & 1 \\
\hline & & Ayrint1 & 1 \\
\hline & & Üst düzey deneyler & 1 \\
\hline & $\begin{array}{l}\text { Kategori 2: Yöntem } \\
\text { Alt kategori 1: Yaparak yaşayarak }\end{array}$ & Aktif öğrenme (öğrenci merkezli) & 2 \\
\hline
\end{tabular}


Etkinlik

ögrenme

\begin{tabular}{llr} 
Alt kategori 2: Deneylerin Yapılışı & Gösteri deneyi & 4 \\
& Ders kitabı & 1 \\
\hline & Güvenlik önlemleri & 5 \\
Kategori 3: Tavsiyeler & Öğrencilerin malzeme temini & 2 \\
& Öğretmen rehberliği & 1 \\
& Öğrencileri gruplandırma & 1 \\
& Eğlenceli laboratuvar & 1 \\
& laboratuvar notu & 1 \\
& Ayrı laboratuvar dersi & 1 \\
& Öğretmen-öğrenci ilşkisi & 1 \\
\hline
\end{tabular}

Tablo 3 incelendiğinde fen bilimleri ve laboratuvar uygulamalarında karşılaşılan güçlükler konusunda öğrencilerle yapılan görüşmeler sonucunda mekan ile deney ve etkinlikler şeklinde 2 tema, mekan teması altında laboratuvar ve sınıf şeklinde iki alt temanın elde edildiği görülmektedir. Laboratuvar alt teması; yetersizlik, laboratuvar kullanım sıklığı, istenmeyen durum ve öğrenci davranışları şeklinde belirlenen 4 kategoriden oluşmuştur. Sınıf alt teması, istenmeyen durum kategorisinden oluşmuştur. Deney ve etkinlikler teması ise yetersizlik, yöntem ve tavsiyeler olarak 3 kategoriden olușmuștur. Fen bilimleri dersinin laboratuvarda işlenmesine yönelik 'yetersizlik' kategorisinden elde edilen kodlamalardan yola çıkarak; öğrencilerden çoğunluğu deney malzemesi $(n=11)$, sonra sirasıyla öğrenci tabure ve masası $(n=4)$, malzeme dolabı $(n=3)$, alan büyüklüğü $(n=3)$, su (lavobo, musluk vb.) $(n=2)$, yeni teknolojik aletler $(n=2)$, bir öğrenci laboratuvar kullanım talimatnamesi, bir öğrenci temizlik, bir öğrenci ayrı malzeme odası ve bir öğrenci 1sınmayı laboratuvardaki eksiklikler olarak belirtmişlerdir. Örneğin deney malzemelerinin eksikliği ile ilgili olarak bir öğrenci (Öğ5) daha gelişmiş deney malzemelerinin olmasını isterken, bir başka öğrenci (Öğ2) yapılacak etkinliğe yönelik gerekli deney malzemelerinin olması gerektiğini ifade etmiştir. Bir başka öğrenci (Öğ10) “yani mesela kalp keserken falan eldiven lazım oluyor. o yüzden bir olumsuz durum oluyor. malzeme eksik oluyor (Öğ10)" ifadesini kullanmıştır. Bunların haricinde bir öğrenci (Öğ11) konuyla ilgili olarak "sonra laboratuvar büyük olmalı. tüm öğrencilere göre düzenlenmiş olmalı. başka, dolaplar falan olmalı içine koymak için malzemeleri. sonra sandalye masalar büyük olmalı (Ö11)"; bir diğer öğrenci ise "daha tedbir almalıyız. hani patlama olmaması için. uygun klyafetler, önlem almalıyı (Öğ2)" şeklinde önerilerde bulunmuşlardır.

Öğrencilerle yapılan görüşmeler sonucunda öğrencilerin laboratuvara gelme sıklıklarında farklılıklar olduğu anlaşılmaktadır. Öğrencilerden altısı çok nadir geldiklerini, dördü ara-sıra ve ikisi ayda 1-2 kez geldiklerini belirtirken, bir öğrenci de her hafta laboratuvara geldiğini belirtmiştir.

Fen bilimleri dersinin laboratuvarda işlenmesine yönelik 'istenmeyen durum' kategorisinden elde edilen kodlamalara bakıldığında, öğrencilerin dördünün 'oturma düzeni ve gürültü'ye, ikisi ise ‘öğrenci sayısının fazla olması'na dikkat çektiği gözlenmektedir. Örneğin bir öğrenci (Öğ10) deney yapılırken gürültü yapıldığını ifade ederken, diğer bir öğrenci (Öğ7) "bu masalar bu şekilde olmazdl. daha çok U şeklinde yapardım masaları. Ögretmen ortaya geçip herkesin görebileceği şekilde olmalı.", bir başka öğrenci (Ö̈̆1) ise "mesela mikroskopla inceleme yapıyoruz. Onu sırayla yapmaya çalışıyoruz, ama maalesef yapamıyoruz çünkü sınıflar kalabalık oluyor. O yüzden de çok şey olmuyor. sıra gelmediği için." șeklinde görüş belirtmiştir. Bunların haricinde bir öğrenci de (Öğ1 "böyle bir şeyle ilgilenirken bir deney yaparken böyle herkes onu yapmak istiyor mesela. Hani ben yapacağım, ben yapacağım isteği var ya, işte onu yenememeleri" şeklinde görüş belirterek öğrencilerdeki aşırı isteklilikten rahatsız olduğunu ifade etmiştir.

Tablo 3’te görüldüğü üzere, fen bilimleri dersinin sınıfta işlenmesine yönelik 'istenmeyen durum' kategorisinden elde edilen kodlamalar dikkate alındığında öğrencilerden dördünün 'arkadaşlar arası davranışlar'; üçünün 'gereksiz öğrenci konuşması'; ikisinin 'gürültü'; birinin 'konuları anlayamamak' ve birinin ise 'dikkat dağınıklığına' dikkat çektiği görülmektedir. Örneğin bir öğrenci (Öğ3) arkadaşlarını rahatsız etmemelerini belirtirken, diğer bir öğrenci (Öğ2) arkadaşlarının kendi aralarında konuşmasından rahatsız olduğunu belirtmiştir. Bir başka öğrenci (Öğ13) "Mesela iki tane arkadaşım bana dokunuyor. Ben orada hoca söylerken aklımdan gidiyor.", bir diğer öğrenci ise (Öğ1) "Bazen 
anlayamadığım konular olabiliyor. Böyle bazen nasıl desem arkadaşlar arasında anlaşmazlık çıkabiliyor. Çok ses gürültü̈sü olduğundan konuları bazen anlamayabiliyoruz. Bu tür sorunlar...” şeklinde görüş belirtmiştir.

Fen bilimleri dersinin ișlenișine yönelik deney ve etkinlik temasındaki 'yetersizlik' kategorisinden elde edilen kodlamalardan yola çıkılarak, bir öğrencinin öğrenme amac1, bir öğrencinin ayrıntı ve bir öğrencinin ise üst düzey deneylere dikkat çektiği görülmektedir. Bir öğrenci (Öğ12) yapılan deneylerin modern olmadığını ifade ederken, diğer bir öğrenci (Öğ7) "Deneyleri yaparken ögretmen istediği için değil de öğrenme amaçl yapmalıyız.", bir başka öğrenci (Öğ9) ise "Mesela bugün kalbi kestik. Mesela içine mikroskopla falan bakmamız lazım. İște detaylı bakmalıyız." şeklinde görüş belirtmiştir. Fen bilimleri dersinin işlenişine yönelik deney ve etkinlik temasındaki 'yaparak yaşayarak öğrenme' alt kategorisinden elde edilen kodlamalardan yıla çıkıldığında iki öğrencinin 'aktif öğrenme (ögrrenci merkezli)', 'deneylerin yapılıșı' alt kategorisinden yola çıkılarak ise dört öğrencinin 'gösteri' deneyine, bir öğrencinin 'ders kitabı'na dikkat çektiğgi görülmektedir. Örneğin bir öğrenci (Öğ8) gösteri deneyi yapılmasını doğru bulurken, diğer bir öğrenci(Öğ7) "Her ögrenci kendi yapmall. Bir tane yapıp herkese gösterilmemeli. Herkes kendisi istediği gibi yapmalı", bir başka öğrenci ise (Öğ6) "Herkes deneyini kendisi yapmall, ayrıntıl bir şekilde ama kitapta nasıl gösteriliyorsa o şekilde." şeklinde görüş belirtmiştir.

Fen bilimleri dersinin işlenişine yönelik deney ve etkinlik temasındaki 'tavsiyeler' kategorisinden elde edilen kodlamalardan yola çıkılarak beş öğrencinin deney için güvenlik önlemleri alınmasına, iki öğrencinin deney malzemelerini öğrencilerin kendilerinin temin etmesine, bir öğrencinin deneylerde öğrenci gruplandırması yapılmasına, bir öğrencinin öğretmen rehberliği olmasına, bir öğrencinin eğlenceli laboratuvara, bir öğrencinin laboratuvar notuna, bir öğrencinin ayrı laboratuvar dersi olmasına ve bir öğrencinin öğretmen-öğrenci ilişkisine dikkat çektiği görülmektedir. Örneğin bir öğrenci (Öğ12) deney sırasında öğretmenlerin öğrencilerin yanında olmasını, bir başka öğrenci (Öğ7) güvenlik önlemleri alınmasını belirtirken, diğer bir öğrenci (Öğ9) "Mesela bugün kalbi kestiğimizde ögretmen kimseye dokundurtmadl. Kendisinin elinde eldiven vardı bizde yoktu. Herkes evinden eldiven getirip o kalbe dokunması lazımdı.", bir başka öğrenci (Öğ11) ise "Mesela karnemizde bütün yaptı̆̆ımı deneyler için de not olmalı. Yani yapılan deneyler karnede gösterilmeli" şeklinde görüş belirtmişlerdir. Öte yandan bir öğrenci (Öğ2) "Daha çok tedbir almallyız. Hani patlama olmaması için. Uygun klyafetler, önlem almalıyız" ve diğer bir öğrenci (Öğ12) ise "Ayrı bir ders olarak yapardım laboratuvarı. Fen bilimlerinden ayrı bir ders olarak" şeklinde tavsiye niteliğinde görüş bildirmiştir.

Fen bilimleri dersinde sinıf ortamında yapılan gözlemlerden elde edilen tema, kategori ve kodlar Tablo 4'te verilmiştir.

Tablo 4 incelendiğinde yapılan gözlemlerde öğrenim görülen sınıfların büyüklüğünün yetersiz olduğu ve mevcudunun kalabalık olduğu görülmüştür. Sınıftayken dört öğretmenin tamamının fen bilimleri dersinde düz anlatım ve soru-cevap tekniğini kullandığ 1 , bunun yanında bir öğretmenin problem çözme tekniğini kullanarak ders anlattığı görülmektedir. Ayrıca iki öğretmen derslerinde deney yapmakta, bunu gösteri deneyi şeklinde yapmaktadır. Derslerde öğretmenlerin; tamamı ders kitabını, üçü defter ve yazı tahtasını, ikisi akıllı tahtayı, ikisi etkinlik yaptıklarında etkinlik malzemesini ve biri çalışma kağıdını ders materyali olarak kullanmaktadır. Öğretmenlerin; tamamının derslerde ögrencilerine isimleri ile hitap ettikleri ve öğrencilerinin sorularına veya yanlış ifadelerine anında dönüt verdikleri, çoğunluğunun (üçünün) sınıfta dolaşarak ders anlattıkları tespit edilmiştir. Bunların yanında iki öğretmenin öğrencilerin cevaplarına aferin, teşekkür ederim şeklinde pekiştireç verdikleri ve öğrencilere rehberlik yaptıkları görülmektedir. Ayrıca bir öğretmenin konuları yüksek sesle anlattığı belirlenmiştir. Öte yandan öğretmenlerin tamamının kibarca ve çoğunluğunun (üçünün) güler yüzle derslerini anlattıkları tespit edilmiştir. Bunun yanında farklı beden dillerini kullandıkları da gözlenmiştir. Dersleri işlerken yeri geldiğinde iki öğretmenin öğrencilerine gülümseyerek, üç öğretmenin öğrencilerle istenmeyen durumla karşılaşıldığında göz teması kurarak ve üç öğretmenin o anki yüz ifadesini değiştirerek tepki verdikleri gözlemlenmiştir. 
Tablo 4. Gözlem sonuçlarından elde edilen tema, kategori ve kodlar

\begin{tabular}{|c|c|c|c|c|}
\hline Tema & Alt Tema & Kategori & Kod & f \\
\hline \multirow{36}{*}{ 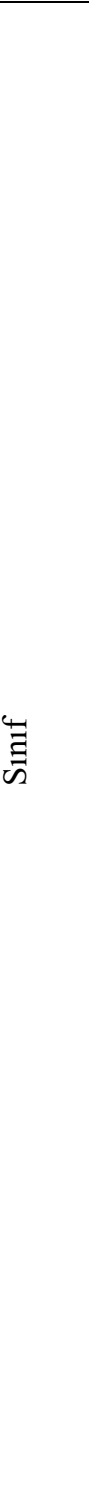 } & Fiziki özellikler & Yetersizlik & Alan büyüklüğü & 4 \\
\hline & & Kalabalıklık & 35 öğrenci & 2 \\
\hline & & & 33 öğrenci & 1 \\
\hline & & & 36 öğrenci & 1 \\
\hline & \multirow{22}{*}{ Öğretmen } & \multirow{4}{*}{ Yöntem ve teknik } & Düz anlatım & 4 \\
\hline & & & Soru-cevap & 4 \\
\hline & & & Gösterip yaptırma & 2 \\
\hline & & & Problem çözme & 1 \\
\hline & & \multirow{7}{*}{ Materyal } & Ders kitab1 & 4 \\
\hline & & & Defter & 3 \\
\hline & & & Ak1lli tahta & 3 \\
\hline & & & & \\
\hline & & & Yaz1 tahtas1 & 3 \\
\hline & & & Etkinlik malzemesi & 2 \\
\hline & & & Çalışma kağıdı & 1 \\
\hline & & \multirow{6}{*}{ Davranış } & İsimle hitap etme & 4 \\
\hline & & & Dönüt verme & 4 \\
\hline & & & Sınıfta dolaşma & 3 \\
\hline & & & Rehberlik & 2 \\
\hline & & & Pekiştireç verme & 2 \\
\hline & & & Yüksek sesle konuşma & 1 \\
\hline & & \multirow{2}{*}{ Duyuşsal özellik } & Kibarlik & 4 \\
\hline & & & Güleryüz & 3 \\
\hline & & \multirow{3}{*}{ Beden dili } & Göz teması & 3 \\
\hline & & & Gülümseme & 2 \\
\hline & & & Olumsuz yüz ifadesi & 1 \\
\hline & \multirow[t]{10}{*}{ Öğrenci } & \multirow{10}{*}{ İstenmeyen davranış } & Söz almadan konuşma & 4 \\
\hline & & & Kendi aralarında konuşma & 3 \\
\hline & & & Gürültü & 4 \\
\hline & & & Başka şeyle ilgilenme & 4 \\
\hline & & & Etrafi seyretme & 2 \\
\hline & & & İzinsiz dolaşma & 1 \\
\hline & & & Arkadaşını rahatsız etme & 2 \\
\hline & & & Arkadaşını şikayet etme & 2 \\
\hline & & & Arkadaşlarıyla tartışma & 2 \\
\hline & & & Uyumak & 1 \\
\hline
\end{tabular}

Fen bilimleri dersinde sınıfta yapılan gözlemlerde istenmeyen davranışlar ile ilgili olarak dört öğrencinin gürültü yaptığı, dört öğrencinin kendi aralarında konuştuğu ve dört öğrencinin derste konu anlatılırken kalemi sıraya vurduğu, kalem çevirmek, kalemlikle oynamak gibi başka şeyle ilgilendiği, bunların yanında üç öğrencinin kendi aralarında çok konuştuğu, iki öğrencinin arkadaşları ile tartıştığı, iki öğrencinin etrafı seyrettiği, iki öğrencinin arkadaşını rahatsız ettiği ve iki öğrencinin birbirlerini şikayet ettikleri, bir öğrencinin öğretmenden izin almadan sınıfta dolaştığı ve bir öğrencinin derste uyuduğu tespit edilmiştir. Öğretmenler dersleri veya etkinlikleri laboratuvarda yapmadıkları için ayrıca laboratuvarda gözlem yapılamamıştır. Bu da çalışma kapsamında sınıf yönetimiyle ilgili var olan olumsuz durumların varlığı olarak göze çarpmaktadır.

\section{TARTIŞMA, SONUÇ VE ÖNERILER}

$\mathrm{Bu}$ araştırmanın amac1, ortaokul fen bilimleri dersi ve laboratuvar uygulamalarında karşılaşılan güçlüklerin öğrenci ve öğretmen bakış açısından incelenmesi ve laboratuvar ortamında öğrenci davranışlarının nasıl şekillendiğinin belirlenmesidir. Araştırmada öğretmenlerin görüşlerinden elde edilen verilere göre çoğunlukla laboratuvarda deney malzemesi, elektrik tesisatı ve alan büyüklüğü, malzeme dolabı ve su tesisatı (lavabo, musluk vb.) yönünden; öğrenci görüşlerine göre ise benzer şekilde laboratuvar fiziki şartlarında ve deney malzemelerinde yetersizlikler olduğu sonucu bulunmuştur. Bu bulgulara benzer şekilde alanyazındaki birçok çalışmada da (Akıncı, Uzun ve 
Kışoğlu, 2015; Bozdoğan ve Yalçın, 2004; Demir, Böyük ve Koç, 2011; Güneş, Şener, Germi ve Can, 2013; Kırıkkaya, 2009; Şimşek, Hırça ve Coşkun, 2012; Tekbıyık ve Akdeniz, 2008; Uluçınar, Cansaran ve Karaca, 2004; Uluçınar, Doğan ve Kaya, 2008) fen laboratuvarınını fiziksel ortamının yetersizlikleri ve deney malzemelerinin eksikliği ile ilgili örtüşen sonuçlar gözlenmektedir. Ayrıca, laboratuvardaki öğrenci tabure ve masasının yetersiz olduğu ve laboratuvar kullanım talimatnamesinin olmadığı da görülmüştür. Alanyazında fen öğretimi ve laboratuvar uygulamalarına ilişkin elektrik donanımlarının denetlenmediği ve deney uygulama kılavuzunun olmadığı bulguları (Uluçınar vd., 2008; Uluçınar vd. 2004) ile bu araştırmanın bulguları da örtüşmektedir.

Çalışmada öğretmenlerin çoğunluğunun deney ve etkinliklerin laboratuvarda ara sıra ya da ayda bir iki kez yapıldığını belirttikleri görülmektedir. Öğrencilerin çoğunluğu ise deneylerin nadiren veya ara sıra laboratuvarda yapıldığını belirtmiştir. Yapılan gözlemlerde de öğretmenlerin deney ve etkinlikleri laboratuvarda değil, çoğunlukla sınıflarda yaptığı tespit edilmiştir. Bunun sınıfların kalabalık olmasında, laboratuvardaki malzeme yetersizliğinden, laboratuvarın fiziki şartlarının uygun olmamasından kaynaklandığı düşünülebilir. Çünkü okulun fiziksel donanımı ve araç-gereç durumu öğretim yapılırken uygulamalarda etkinlik yapılmasını olumsuz etkilemektedir (Pehlivan, 2004). Böyük, Demir ve Erol'un (2010) öğretmenlerin yapmaları gereken deneyleri ara sıra yaptıkları ve deney yapmada daha çok derslikleri tercih ettikleri; Engin, Pekmez ve Erdal'ın (2003) benzer şekilde öğretmenlerin sınıfı laboratuvar olarak kullandıkları bulgular bu çalışmadaki verilerle benzerlikler sergilemektedir.

Çalışmada öğretmenlerin, tamamının laboratuvardaki oturma düzenini, çoğunluğunun ise öğrenci sayısının fazlalığını diğer bir deyişle sınıfların kalabalık olmasını ve bunun tehlike oluşturmasını 'istenmeyen bir durum' olarak belirttikleri görülmektedir. Bunun yanında laboratuvarda sınıf ortamına oranla daha fazla gürültü olduğunu belirten öğretmenlerin de olduğu tespit edilmiştir. Öğrencilerin görüşlerinden elde edilen bulgular da bu sonucu desteklemektedir. Araştırma bulgularına göre laboratuvar kullanımı konusunda yönetici ilgisizliğinden rahatsız olduğunu belirten öğretmen de bulunmaktadır. Konu ile ilgili alanyazında yapılan çalışmalarda sınıfların kalabalık olması (Akıncı, Uzun ve Kışoğlu, 2015; Arslan, 2000; Ayvacı ve Durmuş, 2013; Bayraktar ve Çınar, 2010; Çoruhlu, Er Nas ve Çepni, 2009; Doğan, 2010; Geçer ve Özel, 2012; Kırıkkaya, 2009; Küçüköner, 2011; Uluçınar vd., 2004; Uluçınar vd., 2008) ve gürültünün (Türnüklü ve Galton, 2001) istenmeyen durum olduğu belirtilerek çalışma sonucunu destekleyen bulgulara rastlanmıştır. Bunun yanında, Üstün ve Demir (2015)'in fen bilgisi öğretmenlerinin laboratuvar ortamında karşılaştıkları istenmeyen durumları belirlemek amacıyla yaptığı çalışmada, istenmeyen durumla sınıfların mevcudu arasında anlamlı bir farklılık olmadığ 1 belirtilmiştir. Ayrıca Karakolcu (2009) okuldaki yöneticilerin ilgisiz davranmaları konusunda öğretmenlerin laboratuvar kullanımına yönelik isteksizliklerini ve Uluçınar vd. (2008) yaptıkları çalışmalarda öğretmenlerin, okul yönetiminin laboratuvar konusundaki ilgisizliklerini belirtiklerini ifade ederek çalışma bulgularıyla benzer sonuçlar bulmuşlardır.

Araştırmada öğretmenlerin yarısı sınıftaki gürültü olduğunu ve sınıf mevcudunun kalabalık olduğunu belirtmiştir. Öğrencilerden de benzer şekilde gürültüden rahatsız olduklarını belirten öğrenciler bulunmaktadır. Bunun yanında öğrenciler derste kendi aralarında konuştukları için rahatsız olduklarını dile getirmiştir. Yapılan gözlemlerde de sınıfların kalabalık olduğu, sınıfların sınıf mevcuduna göre alan büyüklüklerinin yetersiz olduğu, öğrencilerin derste gürültü yaptıkları, kendi aralarında konuştukları, yüksek sesle tartıştıkları ve söz almadan, izinsiz konuştukları tespit edilmiştir. Derslerde fazla gürültünün yaşanmasının nedeni olarak sınıflardaki öğrenci mevcudunun fazla olmasının yanında öğrencilerin konuya olan ilgilerinin çekilememiş olmasından kaynaklandığı söylenebilmektedir. Konu ile ilgili alanyazında yapılan çalışma bulguları da bu sonucu destekler niteliktedir. Örneğin, Türnüklü ve Galton (2001) çalışmasında öğrencilerin sınıfta gürültü yaptıklarını ve izin almadan konuştuklarını, Çetin (2013), benzer şekilde öğrencilerin izinsiz konuştuklarını ve Çapri, Balcı ve Çelikkaleli (2010) öğrencilerin söz verilmeden konuştuklarını ve birbirlerini rahatsız ettiklerini belirterek çalışma sonucuyla örtüşen bulgular tespit etmişlerdir.

Çalışmada fen bilimleri dersinde deney ve etkinliklerin yapılması konusunda öğretmen görüşlerinden elde edilen sonuçlara göre öğrenciler derste deney ve etkinlikler yaptıklarında yaparak yaşayarak öğrenmektedir. Bunun sonucunda kalıcı ve anlamlı öğrenme gerçekleşmektedir. Ayrıca öğrencilerin 
derse yönelik ilgileri de artmaktadır. Öte yandan öğretmenlerin çoğunluğu laboratuvar uygulamaları yapılırken öğrencileri gruplandırma, laboratuvarda güvenlik önlemlerinin alınmasını, öğrencilere rehberlik yapılması yeterli deney malzemelerinin temin edilmesi tavsiyesinde bulunmuştur. Öğrencilerle yapılan görüşmelerin sonucunda da öğrencilerin çoğunluğu laboratuvarda güvenlik önlemleri alınması tavsiyesinde bulunmuşlardır. Bununla birlikte öğrenciler laboratuvarda, öğretmenler tarafından kendilerine rehberlik yapılması, kendilerinin malzeme teminini sağlamasını, karnede fen bilimleri dersinden ayrı olarak laboratuvar notunun olmasını ve ayrı bir ders olarak laboratuvar dersinin olmasını tavsiye etmişlerdir. Böyük vd. (2010)'nin fen ve teknoloji dersi öğretmenlerinin laboratuvar şartları ve kullanımına ilişkin görüşlerini belirlediği çalışmasında öğretmenlerin, laboratuvar çalışmaları yapıldığında öğrencilerin yaparak yaşayarak öğrendiğini ve bunun kalıcılığı sağladığını düşündüklerini belirterek çalışma sonucuyla benzer sonucu bulmuştur. Uluçınar, Cansaran, ve Karaca (2004) ile Uluçınar, Doğan ve Kaya (2008)'nın çalışmalarında da laboratuvarda güvenlik donanımlarının ve önlemlerinin eksik olduğu bulgusu araştırma sonucunu desteklenmektedir.

Araştırmada elde edilen bir diğer sonuç deneylerin çoğunlukla gösteri deneyi şeklinde yapılmasıdır. Yapılan gözlemlerde de deneylerin, gösteri deneyi olarak yapıldığı görülmüştür. Bunun, laboratuvarda gerekli güvenlik önlemlerinin (ilkyardım malzemeleri, yangın söndürücü tüpü, eldiven, gözlük vb. ), yeterince deney malzemelerinin olmamasından kaynaklandığı söylenebilir. Alanyazın incelendiğinde, bu çaloışmada da gözlendiği gibi, fen ve teknoloji dersinde laboratuvar kullanımını gerektiren deneylerin öğretmenlerin basit malzemeler getirerek yalnızca gösteri deneyi şeklinde yapıldığına ilişkin bulgulara rastlanırken (Güneş, Şener, Germi, ve Can, 2013; Uluçınar, Cansaran, ve Karaca, 2004); gösterinin yanı sıra, öğrencilerin de deneye kısmen de olsa katıldığg bulgusunun yer aldığı araştırmalar da (Uluçınar, Doğan ve Kaya, 2008) mevcuttur.

Çalışmada elde edilen bir başka sonuç, öğretmenlerin sınıfta ders işlerken öğretim yöntem ve tekniklerinden çoğunlukla anlatım ve soru-cevap tekniğini kullanmalarıdır. Öğretmen ders kitabını dersin ana materyali olarak görmekte ve kullanmaktadır. Bununla birlikte yazı tahtası, defter ve akıllı tahtalardaki öğretim videoları çoğunlukla ders araç-gereci olarak kullanılmaktadır. Öğretmenlerin daha çok anlatım ve soru-cevap tekniğini kullanmalarının nedeni olarak, kullanılan yöntemlerin kolay olması; deney ve etkinlik yapmak ya da problem çözme, beyin firtınası, altı şapka düşünme tekniği gibi öğretim tekniklerini kullanabilmek için sınıfların kalabalık olması ve ders saatinin yeterli olmaması, öğrenciyle birebir ilgilenmenin zor olmasını göstermişlerdir. Her ne kadar öğretmenler ögrencilerin yaparak yaşayarak öğrenmelerini isteseler de belirtilen nedenlerden dolayı çoğunlukla öğretmen merkezli bir öğretim süreci yürütüldüğü söylenebilir. Alanyazındaki bir çok çalışmada da (Aktepe ve Aktepe, 2009; Doğru ve Aydoğdu, 2003; Geçer ve Özel, 2012; Kurtuluş ve Çavdar, 2011; Solmaz, 2007; Şimşek, Hırça, ve Coşkun, 2012) öğretmenlerin çoğunlukla anlatım ve soru cevap tekniğini kullandıkları, yazı tahtasının ve ders kştabının başlıca materyaller olduğu yönündeki çalışma sonucuyla benzer sonuçlar bulunmuştur.

Çalışmada elde edilen sonuçlar ışığında aşağıdaki önerilerde bulunulabilir:

1. Öğrenciler, yapılacak deneylerle ilgili deney öncesinde bilgilendirilebilir.

2. Öğrenmelerin kalıcı olması bakımından etkin öğrenmeye dayalı öğrenci merkezli yaklaşım, yöntem ve tekniklere daha sıklıkla başvurulabilir.

3. Bu çalışma farklı okul tiplerinde ve sosyo-ekonomik çevreden okullarda tekrarlanabilir.

4. Öğretmenlere laboratuvar kullanımı konusunda hizmet içi eğitimler verilebilir.

5. Öğrenciler laboratuvar kültürünü ve değerlerini kazanmaları konusunda bilinçlendirilmelidir. 
Bilgilendirme / Acknowledgement:

1- Araştırmacıların katkı oranı: 1. Yazar, Ramazan Soğukpınar (\%60); 2. Yazar, Kerim Gündoğdu (\%40)

2- Makalenin yazarları arasında çıkar çatışması bulunmamaktadır.

3- Makalemizde herhangi bir denel işlem yapılmamıştır. Tamamen gönüllü bir katılıma dayalı çalışmadır. İlk yazarın görev yaptı̆̆ı okulda yönetim, ögrenciler ve velilerinden onay alınarak, tamamen gönüllük üzerine yürütülen betimsel bir çalışmadır.

Veriler 2019 yılında toplanmış ve yorumlanmıştır.

4- $\mathrm{Bu}$ makalede araştırma ve yayın etiğine uyulmuştur.

\section{KAYNAKÇA}

Akıncı, B., Uzun, N. ve Kışoğlu, M. (2015). Fen bilimleri öğretmenlerinin meslekte karşılaştıkları problemler ve fen öğretiminde yaşadıkları zorluklar. International Journal of Human Sciences, 12(1), 1189-1215.

Alkaş, B. (2010). İlköğretim öğrencileri arasındaki istenmeyen öğrenci davranışlarının incelenmesi. Yayımlanmamış yüksek lisans tezi, Ankara Üniversitesi Eğitim Bilimleri Enstitüsü, Ankara.

Arslan, M. (2000, Eylül). İlköğretim okullarında fen bilgisi öğretimi ve belli başlı sorunları (Kayseri ili örneklemi). IV. Fen Bilimleri Eğitimi Kongresi, Hacettepe Üniversitesi Eğitim Fakültesi, Ankara.

Bada, S. O. (2015). Constructivism learning theory: A paradigm for teaching and learning. IOSR Journal of Research, \& Method in Education (IOSR-JRME), 5(6), 66-70.

Arslan, M. (2000). İlköğretim okullarında fen bilgisi öğretimi ve belli başlı sorunları (Kayseri ili örneklemi). IV. Fen Bilimleri Eğitimi Kongresi. 119-124. Ankara: Milli Eğitim Basımevi.

Aydoğdu, C. ve Yardımcı, E. (2013). İlköğretim fen laboratuvarlarında meydana gelen kazalar ve öğretmenlerin geliştirebilecekleri davranış tarzları. Hacettepe Üniversitesi Eğitim Fakültesi Dergisi, 44(44), 52-60.

Ayvacı, H.Ş. ve Durmuş, A. (2013). Fen ve teknoloji öğretmenlerinin mesleklerinin ilk yıllarında karşılaştıkları sorunlar ve bu sorunların yıllara göre değişimi. Atatürk Üniversitesi Kazım Karabekir Ĕ̌itim Fakültesi Dergisi, 27, 29-44.

Balım, A. G., Kesercioğlu, T., Evrekli, E., ve İnel, D. (2009). Fen öğretmen adaylarına yönelik yapılandırmacı yaklaşım görüş ölçeği: Bir geçerlilik ve güvenirlik çalışması. İnönü Üniversitesi Eğitim Fakültesi Dergisi, 10(1), 79-92.

Başdaş, E., Kirişcioğlu, S. ve Oluk, S. (2006). Fen öğretiminde yapılandırmacı kuram bağlamında Hands-On Yöntemi: Önemi, örnek uygulamalar ve değerlendirme. Yap1landırmac1lık ve Eğitime Yansımaları Sempozyumu, 29 Nisan, İzmir.

Bayraktar, Ş. ve Çınar, D. (2010). Öğretmen adaylarının gözü ile fen ve teknoloji öğretmenlerinin etkili öğretmen davranışlarını gerçekleştirme düzeyleri. Ahi Evran Üniversitesi Ĕgitim Fakültesi Dergisi, 11(3), 131-152.

Baysal, Y. E. ve Mutlu, F. (2019). Cinsiyetin fen laboratuvarına yönelik tutum üzerinde etkisi: bir meta-analiz çalışması (Türkiye örneği). Kastamonu Ĕgitim Dergisi, 27(5), 1911-1920.

Baysal, Y.E., Mutlu, F. ve Kış, A. (2019). Çağdaş yaklaşımlara dayalı laboratuvar uygulamalarının Türkiye'deki öğrencilerin laboratuvar derslerindeki tutumlarına etkisi: Bir meta-analiz çalışması. Bolu Abant İzzet Baysal Üniversitesi Eğitim Fakültesi Dergisi, 19(3), 802-817.

Bozdoğan, A.E. ve Yalçın, N. (2004). İlköğretim fen bilgisi derslerindeki deneylerin yapılma sıklığı ve fizik deneylerinde karşılaşılan sorunlar. G.Ü. Kırşehir Eğitim Fakültesi Dergisi, 5(1),59-70.

Böyük, U., Demir, S. ve Erol, M. (2010). Fen ve teknoloji dersi öğretmenlerinin laboratuvar çalışmalarına yönelik yeterlilik görüşlerinin farklı değişkenlere göre incelenmesi. TÜBAV Bilim, 3(4), 342-349. 
Böyük, U., Demir, S. ve Erol, M. (2010). Fen ve teknoloji dersi öğretmenlerinin laboratuvar çalışmalarına yönelik yeterlik görüşlerinin farklı değişkenlere göre incelenmesi. TÜBAV Bilim Dergisi, 3 (4), 342-349.

Ceylan, E., Güzel Yüce, S. ve Koç, Y. (2019). Öğretmenlik yolunda fen öğretimi laboratuvar uygulamaları dersi: Bir durum çalışması. Atatürk Üniversitesi Kazım Karabekir Eğitim Fakültesi Dergisi, 39, 22-47.

Creswell, J. W. (2018). Nitel araştırma yöntemleri beş yaklaşıma göre nitel araştırma ve desenleri. (Çev. Mesut Bütün, Selçuk Beşir Demir). 4.baskı. Ankara: Siyasal Kitapevi.

Çapri, B , Balcı, A. ve Çelikkaleli, Ö . (2010). İlköğretim öğretmenlerinin sınıf içi istenmeyen davranışlara ilişkin görüşlerinin karşılaştırılması. Mersin Üniversitesi Eğitim Fakültesi Dergisi, 6(2), 89-102 .

Çetin, B. (2013). Sınıfta istenmeyen öğrenci davranışlarıyla ilgili sınıf öğretmenlerinin karşılaştıkları sorunlar ve çözüm önerileri. Ahi Evran Üniversitesi Kırşehir Eğitim Fakültesi Dergisi (KEFAD),14(1), 255-269.

Çınar, D. ve Kurt, H. (2019). Biyoloji öğretmen adaylarının laboratuvara yönelik semantik farklılıkların belirlenmesi. Kırşehir Eğitim Fakültesi Dergisi, 20(3), 1175-1202.

Çoruhlu, T.Ş., Er Nas, S. ve Çepni, S. (2009). Fen ve teknoloji öğretmenlerinin alternatif ölçmedeğerlendirme tekniklerini kullanmada karşılaştıkları problemler: Trabzon örneği. Yüzüncü Yıl Üniversitesi Ĕ̌itim Fakültesi Dergisi, 6(1), 122-141.

Daşdemir, İ. ve Doymuş, K. (2012). Fen ve teknoloji dersinde animasyon kullanımının öğrencilerin akademik başarılarına, öğrenilen bilgilerin kalıcıllı̆ına ve bilimsel süreç becerilerine etkisi. Pegem Ĕ̈itim ve Öğretim Dergisi, 2(3), 33-42.

Demir, S , Böyük, U. ve Koç, A . (2012). Fen ve teknoloji dersi öğretmenlerinin laboratuvar şartları ve kullanımına ilişkin görüşleri ile teknolojik yenilikleri izleme eğilimleri. Mersin Üniversitesi Eğitim Fakültesi Dergisi, 7(2) , 66-79.

Doğan, Y. (2010). Fen ve teknoloji dersi programının uygulanması sürecinde karşılaşılan sorunlar. Yüzüncü Yıl Üniversitesi Eğitim Fakültesi Dergisi, 7(1), 86-106.

Doğru, M. ve Aydoğdu, P. (2003). Fen bilgisi öğretiminde kullanılan yöntemlerde karşılaşılan sorunlar ile ilgili öğrenci görüşleri. Pamukkale Üniversitesi Eğitim Fakültesi Dergisi, 13(13) , 150-158.

Durmuş, Z. (2019). FeTeMM etkinlik merkezli laboratuvar dersinin sınıf öğretmenliği adaylarının fen ögretimine yönelik öz-yeterlik ve problem çözme becerileri üzerine etkileri. Yayımlanmamış yüksek lisans tezi, Kırşehir Ahi Evran Üniversitesi Fen Bilimleri Enstitüsü, Kırşehir.

Erdemir, N. (2007). Mesleğine yeni başlayan fen bilgisi öğretmenlerinin karşılaştıkları sorunlar ve şikayetleri. Elektronik Sosyal Bilimler Dergisi, 6(22), 135-149.

Geçer, A. ve Özel, R. (2012). İlköğretim fen ve teknoloji dersi öğretmenlerinin öğrenme-öğretme sürecinde yaşadıkları sorunlar. Kuram ve Uygulamada Eğitim Bilimleri, 12(3), 1-26.

Keskin Geçer, A. (2018). Fen bilgisi ögretmenlerinin laboratuvar uygulamalart ile ilgili yeterlilikleri, tutumları ve karşılaşılan problemler. Yayımlanmamış doktora tezi, Fırat Üniversitesi Eğitim Bilimleri Enstitüsü, Elazığ.

Gökyer, N. ve Doğan, B. (2016). İstenmeyen öğrenci davranışları ve nedenlerine ilişkin yönetici ve öğretmen görüşleri. Firat Üniversitesi Sosyal Bilimler Dergisi, 26(1), 93-105.

Güneş, M.H., Şener, N., Germi, N.T. ve Can, N. (2013). Fen ve teknoloji dersinde laboratuvar kullanımına yönelik öğretmen ve öğrenci değerlendirmeleri. Dicle Üniversitesi Ziya Gökalp Ĕ̈itim Fakültesi Dergisi, 20, 1-11. 
Harman, G. (2011). Analysis of the prospective elementary teachers' informations about laboratory equipments that are used in science and technology teaching. International Conference on New Trends in Education and Their Implications, 27-29 April, Antalya, Türkiye.

Hofstein, A., \& Lunetta, V.N. (2003). The laboratory in science education: Foundations fort he twenty-first century. Science Education, 88(1), 28-54.

Hofstein, A., \& Mamlok-Naamon, R. (2007). The laboratory in science education: the state of the art. Chemistry Education Research and Practice, 8(2), 105-107.

İdin, Ş. ve Aydoğdu, C. (2016). Asit ve bazın tahribatları etkinliğinin laboratuvar kullanım teknikleri açısından incelenmesi üzerine bir uygulama çalışması. Amasya Üniversitesi Eğitim Fakültesi Dergisi, 5(2), 606-635.

Kaplan, M. (2011). İlköğretim öğrencilerinin fen ve teknoloji dersi öğrenme ve öğretme ortamına yönelik düşünceleri. Eğitim ve Insani Bilimler Dergisi: Teori ve Uygulama, 2(4), 77-92.

Karaca, A., Uluçınar, Ş. ve Cansaran, A. (2006). Fen bilgisi eğitiminde laboratuvarda karşılaşılan güçlüklerin saptanmas1. Milli Eğitim Dergisi, 34(170), 1-7.

Karakolcu, E. (2009). Fen ve teknoloji öğretim programında yer alan deney ve etkinliklerin uygulanabilirliğine ilişsin ögretmen görüşleri. Yayımlanmamış yüksek lisans tezi, Karadeniz Teknik Üniversitesi Fen Bilimleri Enstitüsü, Trabzon.

Ketpichainarong, W., Panijpan, B.,, \& Ruenwangsa, P. (2010). Enhanced learning of biotechnology students by an inquiry-based cellulase laboratory. International Journal Environmental, \& Science Education, 5(2), 169-187.

Kılıç, M.S. ve Aydın, A. (2018). Öğretmenlerin fen bilimleri dersi kapsamında laboratuvar uygulamaları hakkındaki görüşlerinin planlanmış davranış teorisi yardımıyla incelenmesi. Kastamonu Ë̆itim Dergisi, 26(1), 241-246.

Kılıç, D., Keleş, Ö. ve Uzun, N. (2015). Fen bilimleri öğretmenlerinin laboratuvar kullanımına yönelik özyeterlilik İnançları: Laboratuvar uygulamaları programının etkisi. Erzincan Üniversitesi Eğitim Fakültesi Dergisi, 17(1), 218-236.

Kırıkkaya, E. B. (2009). İlköğretim okullarındaki fen öğretmenlerinin fen ve teknoloji programına ilişkin görüşleri. Türk Fen Eğitimi Dergisi, 6(1), 133-148.

Kırpık, M. A. ve Engin, A.O. (2009). Fen bilimlerinin öğretiminde laboratuarın yeri önemi ve biyoloji öğretimi ile ilgili temel sorunlar. Kafkas Üniversitesi Fen Bilimleri Enstitüsü Dergisi, 2(2), 61-72.

Kızıkcık, H. Ş., Çağan, S. ve Ünlü Yavaş, P. (2019). Dokuzuncu sınıf öğrencilerinin fizik laboratuvarı malzemelerini tanıma düzeyleri. Illkögretim Online, 18(1), 190-206.

Kurtuluş, N. ve Çavdar, O. (2011). Fen ve teknoloji öğretim programındaki etkinliklere yönelik öğretmen ve öğrenci düşünceleri. Necatibey Eğitim Fakültesi Elektronik Fen ve Matematik Ĕ̈itimi Dergisi (EFMED), 5(1), 1-23.

Küçüköner, Y. (2010). 8. sinıf fen ve teknoloji dersinde kullanılan laboratuvar araç-gereçlerinin MEB'in belirlediği hedef kazanımlarla ilişkisi ve bu araç-gereçlere yönelik ögretmen görüşlerinin incelenmesi (Bingöl örneği). Yayımlanmamış yüksek lisans tezi, Erzincan Üniversitesi Fen Bilimleri Enstitüsü, Erzincan.

Levitt, K. (2001). An analysis of elementary teachers' beliefs regarding the teaching and learning of science. Science Education, 86, 1-22.

Miles, M. B., \& Huberman, A. M. (1994). Qualitative data analysis : An expanded sourcebook. 2nd Edition. Thousand Oaks, CA: Sage.

Milli Eğitim Bakanlığ1 (MEB) 2006. İlköğretim okulları fen ve teknoloji dersi (6, 7 ve 8. sinıflar) ögretim programı. Ankara: Talim ve Terbiye Kurulu Başkanlığı. 
Milli Eğitim Bakanlığı (MEB) 2013. İlköğretim kurumları (ilkokullar ve ortaokullar) fen bilimleri dersi $(3,4,5,6,7$ ve 8. sinıflar) ögretim programı. Ankara: Talim ve Terbiye Kurulu Başkanlığgl.

Milli Eğitim Bakanlığı [MEB] (2018). Fen bilimleri dersi (ilkokul ve ortaokul 3, 4, 5, 6, 7 ve 8. sinıflar) öğretim programı. Ankara: Talim ve Terbiye Kurulu Başkanlığı.

Milli Eğitim Bakanlığı (MEB). (2019). PISA 2018 Türkiye ön raporu. 4 Mayıs 2020 tarihinde http://pisa.meb.gov.tr/wpcontent/uploads/2020/01/PISA_2018_Turkiye_On_Raporu.pdf adresinden erişildi.

Orbay M., Özdoğan T., Öner, F., Kara M., ve Gümüş, S. (2003). Fen bilgisi laboratuvar uygulamalar1 I-II dersinde karşılaşılan güçlükler ve çözüm önerileri. Milli Eğitim Dergisi, 157. 17 Ocak 2020 tarihinde https://dhgm.meb.gov.tr/yayimlar/dergiler/Milli_Egitim_Dergisi/157/orbay.htm adresinden erişildi.

Pala, A. (2005). Sınıfta istenmeyen öğrenci davranışlarını önlemeye dönük disiplin modelleri. Kırgizistan-Türkiye Manas Üniversitesi Sosyal Bilimler Dergisi, 13, 171-179.

Parlaktaş, B. (2018). Fen bilgisi öğretmen adaylarının laboratuvar ortamında öğrendikleri ile bilişsel esneklikleri arasındaki ilişki. Yayımlanmamış yüksek lisans tezi, Aydın Adnan Menderes Üniversitesi Fen Bilimleri Enstitüsü, Aydın.

Solmaz, A. (2007). Fen bilgisi ögrretiminde kullanılan ögrretim yöntemleri ve yöntemlerin uygulanışına ilişkin ögrenci görüşleri. Yayımlanmamış yüksek lisans tezi, Gazi Üniversitesi, Ankara.

Şaşan, H. H. (2002). Yapılandırmacı öğrenme. Yaşadıkça Eğitim, 74-75, 49-52.

Şimşek, H., Hırça, N. ve Coşkun, S. (2013). İlköğretim fen ve teknoloji öğretmenlerinin öğretim yöntem ve tekniklerini tercih ve uygulama düzeyleri: Şanlıurfa ili örneği. Mustafa Kemal Üniversitesi Sosyal Bilimler Enstitüsü Dergisi, 9(18), 249-268.

Taş, U.E., Arıcı, Ö., Özarkan, H.B. ve Özgürlük, B. (2016). Milli Eğitim Bakanlı̆ğ uluslararası ögrenci değerlendirme programı PISA 2015 ulusal raporu. Ankara: MEB.

Tekbıyık, A. ve Akdeniz, A. (2008). İlköğretim fen ve teknoloji dersi öğretim programını kabullenmeye ve uygulamaya yönelik öğretmen görüşleri. Necatibey Ĕgitim Fakültesi Elektronik Fen ve Matematik Eğitimi Dergisi, 2(2), 23-37.

Tuncel, M. ve Fidan, M. (2018, Ekim). Ortaokul fen bilimleri dersinde ögrenmede zorlanılan konular ve çözüm önerileri. 6. Uluslararası Eğitim Programları ve Öğretim Kongresi. 11-13 Ekim, Kafkas Üniversitesi, Kars.

Türkoğlu, İ. ve Dağ, T. (2018). İlköğretimde fen ve teknoloji dersini yürüten öğretmenlerin öğretim sürecinde yaşadıkları sorunlar (Elazığ ili örneği). Turkish Journal of Educational Studies, 5(3), 99-117.

Türnüklü, A., \& Galton, M. (2001). Students’ misbehaviours in Turkish and English primary classrooms. Educational Studies, 27(3), 291-305.

Uluçınar, Ş., Cansaran, A. ve Karaca, A. (2004). Fen bilimleri laboratuvar uygulamalarının değerlendirilmesi. Türk Eğitim Bilimleri Dergisi, 2, 465-475.

Uluçınar, Ş. Doğan, A. ve Kaya, O.N. (2008). Sınıf öğretmenlerinin fen öğretimi ve laboratuvar uygulamalarına ilişskin görüşleri. Kastamonu Ĕ̌itim Dergisi, 16(2), 485-494.

Ültay, N., Dönmez-Usta, N. ve Ültay, E. (2020). Fen eğitimine yönelik öz-yeterliğin öğrenme yaklaşımları ve öğrenme-öğretme ortamına yönelik algılara etkisinin incelenmesi. IBAD Sosyal Bilimler Dergisi, (8), 1-13. 
Üstün, Ö. ve Demir, M.K. (2015). Fen ve teknoloji öğretmenlerinin laboratuvar ortamlarında karşılaştıkları istenmeyen öğrenci davranışlarının incelenmesi. Abant İzzet Baysal Üniversitesi Eğitim Fakültesi Dergisi, 15(1), 281-301.

Yıldız, B., Ilgaz, H. ve Seferoğlu, S. S. (2010, Şubat). Türkiye'de bilim ve teknoloji politikaları: 1963’ten 2013'e kalkınma planlarına genel bir bakış. 457-464. Akademik Bilişim, 10 - XII. Akademik Bilişim Konferansı. 10 - 12 Şubat 2010 Muğla Üniversitesi.

Yin, R., K. (2014). Case study methods: design and method.s (5. Bask1). Thousand Oaks: Sage. 